\title{
STUDI LITERATUR PERSALINAN SC ELEKTIF PADA IBU HAMIL DENGAN HIV/AIDS
}

\section{${ }^{1}$ Yuliana, ${ }^{2}$ Alexander}

Akademi Kebidanan Panca Bhakti Pontianak

Email Korespendensi: yuli.yuliana.uli@gmail.com

\begin{abstract}
Abtrak
Human Immunodeficiency Virus (HIV) adalah virus yang menyerang sel darah putih (sel CD4) dan sehingga tidak dapat digunakan untuk sistem kekebalan tubuh. Persalinan merupakan salah satu pintu masuk Mother to Child HIV Transmission (MTCT) dari ibu kepada bayi melalui darah atau cairan vagina yang terinfeksi virus HIV. Penatalaksanaan pada ibu hamil dengan HIV harus berfokus pada penurunan risiko MTCT dan komplikasi maternal - neonatal melalui metode persalinan caesar secara elektif (ketika viral load > 1000 kopi/ml karena dapat terjadi peningkatan MTCT sebanyak 12 kali lipat. Penelitian ini bertujuan untuk mengetahui pola penularan HIV / AIDS dari ibu kepada bayi. penatalaksanaan persalinan SC elektif pada ibu bersalin dengan HIV / AIDS dan persayaratan yang harus dipenuhi serta mengetahui penatalaksanaan pada bayi baru lahir dari ibu dengan HIV / AIDS. Desain penelitian yang digunakan adalah literatur review. Hasil penelusuran dari google scholar diperoleh dari 5 jurnal sesuai dengan kriteria inklusi. Hasil penelitian ini penularan HIV / AIDS dapat terjadi pada masa kehamilan karena penurunan sel $\mathrm{T}$ dan proses persalinan yang meningkatkan risiko terpapar darah atau cairan vagina yang tertelan bayi pada jalan lahir serta penularan HIV melalui ASI diketahui merupakan faktor penting penularan paska persalinan dan meningkatkan risiko transmisi dua kali lipat. Pada ibu hamil yang positif HIV di sarankan untuk melakukan persalinan secara SC Elektif yang dilakukan satu hingga dua minggu sebelum tanggal kelahiran bayi dan persalinan SC secara Elektif dapat dilakukan jika ada nya kontraindikasi persalinan pervaginam, indikasi fetal dan indikasi maternal. Kesimpulan penelitian ini semua ibu hamil dengan HIV positif disarankan untuk melakukan persalinan dengan seksio sesaria dan persalinan pervaginam yang direncanakan hanya boleh dilakukan oleh wanita yang mengkonsumsi HAART dengan viral load $<50 \mathrm{kopi} / \mathrm{mL}$.
\end{abstract}

Kata kunci: Persalinan, Sectio Caesarean Elektif Pada Ibu Dengan HIV / AIDS

\begin{abstract}
Human Immunodeficiency Virus (HIV) is a virus that attacks white blood cells (CD4 cells) so they cannot be used for the immune system. Childbirth is one of the entry points for Mother to Child HIV Transmission (MTCT) from mother to baby through blood or vaginal fluids infected with the HIV virus. Management of pregnant women with HIV should focus on reducing the risk of MTCT and maternal-neonatal complications through elective caesarean delivery method (when viral load> 1000 copies / $\mathrm{ml}$ because there can be a 12 -fold increase in MTCT. This study aims to determine the pattern of HIV / AIDS transmission from mother to baby, management of elective SC delivery in mothers with HIV / AIDS and the requirements that must be met and knowing the management of newborns from mothers with HIV / AIDS. The research design used was literature review. Google scholar found that 5 journals obtained according to the inclusion criteria. The results of this study that HIV / AIDS transmission can occur during pregnancy because of decreased T cells and the delivery process which increases the risk of exposure to blood or vaginal fluids ingested by babies in the birth canal and transmission of HIV through breast milk is known to be important factor of transmission after delivery and doubles the risk of transmission. Pregnant women who is positive are advised to perform elective cesarean delivery which is carried out one to two weeks before the baby's birth date and elective cesarean delivery can be done if there are contraindications to vaginal delivery, fetal indications and maternal indications. The conclusion of this study that all HIV-positive pregnant women are advised to undergo cesarean section delivery and planned vaginal delivery should only be performed by women taking HAART with viral load <50 copies $/ \mathrm{mL}$.
\end{abstract}

Keywords: Childbirth, elective caesarean section in mothers with HIV / AIDS

\footnotetext{
${ }^{1}$ Dosen Akademi Kebidanan Panca Bhakti Pontianak

${ }^{2}$ Dosen Akademi Kebidanan Panca Bhakti Pontianak
} 


\section{Pendahuluan}

Human Immunodeficiency Virus (HIV) adalah virus yang dapat menyebabkan Acquired Immuno Deficiency Syndrom (AIDS) atau kumpulan berbagai gejala penyakit akibat turunnya kekebalan tubuh individu dengan cara menyerang sel darah putih yang bernama sel CD4 dan merubahnya menjadi tempat berkembangbiak virus HIV baru kemudian merusaknya sehingga tidak dapat digunakan lagi untuk sistem kekebalan tubuh. Penyebaran HIV/AIDS di Indonesia cukup tinggi dari tahun ke tahun dimana jumlah penderitanya semakin bertambah banyak (Rohan H, dkk, 2016).

Lebih dari 20 juta orang meninggal karena infeksi HIV, dan diperkirakan lebih dari 60 juta terinfeksi HIV. Lebih dari 5 juta infeksi baru ditemukannya tiap tahun, sekitar 800.000 diantaranya adalah anak-anak (Rohan H, dkk, 2016). Di negara-negara sub-sahara Afrika prevalensi wanita hamil penderita HIV sekitar $45 \%$. Diperkirakan orang yang hidup dengan pasien HIV sekitar 30juta. HIV / AIDS menjadi pembunuh keempat terbesar dunia.

Berdasarkan laporan Global AIDS update UNAID tahun 2016 jumlah penderita HIV di Dunia pada perempuan usia 15 tahun ke atas adalah sebanyak 17,8 juta dari 36,7 juta kasus HIV pada tahun 2015. Infeksi HIV di indonesia cenderung meningkat dan paling banyak terjadi pada kelompok usia produktif (25-49) (Suherlim, 2015).

Kehamilan adalah proses fisiologis namun tidak dapat dipungkiri bahwa selama kehamilan ibu hamil mengalami penurunan sel $\mathrm{T}$ yang meningkatkan risiko terpapar virus seperti HIV. Kehamilan sering terjadi bersamaan dengan infeksi tergantung pada kemampuan virus melewati plasenta (Rohan H, dkk , 2016). Antibodi yang ditimbulkan oleh infeksi HIV terjadi sejak infeksi berusia $2-3$ bulan. Antibodi ini dapat masuk melalui plasenta menuju janin. Infeksi langsung pada janin mulai terjadi sejak usia 13 minggu dengan mekanisme yang tidak diketahui. Infeksi ini disebut sebagai infeksi vertikal karena berlangsung semasih intrauterin (Manuaba, 2008).

Eliminasi Penularan virus HIV dari Ibu Hamil ke anak / bayi merupakan salah satu target yang diatur dalam Peraturan Menteri Kesehatan Republik Indonesia no 52 tahun 2017 bertujuan mengurangi penularan HIV, sifilis dan hepatitis B dari Ibu ke anak dengan penapisan virus HIV pada seluruh ibu hamil dalam kegiatan pelayanan antenatal terpadu $10 \mathrm{~T}$ di fasilitas kesehatan dasar dengan target $60 \%$ pada tahun 2018 .

Faktor risiko transmisi HIV pada ibu hamil antara lain adalah tingkat pendidikan suami yang rendah, memiliki kondisi ginekologi buruk, konsumsi alkohol, riwayat dirawat dirumah sakit, suami bekerja berpindah - pindah tempat, dan tinggal diperkotaan. Ibu hamil yang terinfeksi HIV memiliki resiko yang lebih besar untuk mengalami aborsi spontan, kehamilan ektopik, dan terjadinya penularan HIV dari ibu ke anak. Penularan dapat terjadi pada masa kehamilan, saat melahirkan, dan saat 
pemberian ASI (Suherlim, 2015).

Eliminasi penularan virus HIV dari ibu ke bayi salah satunya dilakukan dalam beberapa upaya kesehatan promotif untuk meningkatkan pengetahuan dan tanggung jawab masyarakat (ibu hamil sampai menyusui, pasangan seksual) tentang manfaat deteksi dini penularan HIV termasuk perilaku hidup bersih dan sehat, serta meningkatkan peran serta masyarakat untuk turut serta menjaga keluarga sehat sejak dari kehamilan (Permenkes RI, 2017).

Kasus AIDS merupakan fenomena gunung es, yang muncul kepermukaan sebagian kecil dari yang sebenarnya. Pertolongan persalinan yang dilakukan oleh bidan mewajibkan bidan kontak dengan darah, sekresi vagina, cairan amnion, dan cairan tubuh lainnya. Menjadikan bidan memiliki risiko tinggi tertular HIV / AIDS saat melakukan pertolongan persalinan. Risiko infeksi HIV bagi tenaga kesehatan adalah rendah, tetapi bukan 0\%. Cara yang dapat dilakukan oleh bidan untuk mencegah penularan virus tersebut adalah memegang prinsip kewaspadaan universal. ( Afriyanti D, 2012 ).

Penatalaksanaan pada ibu hamil dengan HIV harus berfokus pada penurunan risiko MTCT dan penurunan komplikasi baik pada maternal dan neonatus. Berbagai studi merekomendasikan metode persalinan caesar secara elektif (operasi caesar yang dilakukan sebelum persalinan atau ruptur membran amnion) ketika voral load > $1000 \mathrm{kopi} / \mathrm{mL}$ (Mark S, 2012). The Society of Obstetricians and Gynaecologists of Canada (SOGC) dan American College of Obstetricians and Gynecologists (ACOG) merekomendasikan operasi Caesar terjadwal dilakukan pada ibu hamil yang dengan viral load $1000 \mathrm{kopi} / \mathrm{mL}$ karena dapat terjadi peningkatan MTCT sebanyak 12 kali lipat.

Operasi caesar terjadwal merupakan operasi yang dilakukan sebelum adanya tanda - tanda persalinan atau ruptur membran. Beberapa studi melaporkan adanya ruptur membran dapat mening katkan pajanan janin ke darah dan cairan vagina maternal dan semakin lama durasi ruptur membran dapat meningkatkan faktor risiko transmisi vertikal secara signifikan. Persalinan pervaginam juga dinilai dapat meningkatkan risiko terjadinya peningkatan transmisi infeksi ibu ke anak. Ketika bayi keluar melewati vagina, risiko HIV akan meningkat karena terpapar langsung dengan darah dan sekresi saluran genetal yang sudah terinfeksi (Megadhana $\mathrm{W}, 2015)$.

Menurut Natalova T, 2019 operasi caesar elektif adalah operasi yang dilakukan satu hingga dua minggu sebelum tanggal kelahiran bayi. SC elektif adalah suatu tindakan bedah yang dilakukan terjadwal dengan persiapan, dan dilakukan pada pasien dengan kondisi baik, bukan gawat darurat (Sutarno I, 2017). Menurut Alomedika, 2017 SC elektif adalah tindakan SC terencana yang dilakukan sebelum proses persalinan dimulai. Persalinan harus ditentukan sebelum umur kehamilan 38 minggu untuk meminimalkan terjadinya komplikasi persalinan. Sampel 
plasma viral load dan jumlah CD4 harus diambil pada saat persaslinan.

Pasien dengan HAART harus mendapatkan obatnya sebelum persalinan. Semua ibu hamil dengan HIV positif disarankan untuk melakukan persalinan dengan seksio sesaria. Infus ZDV diberikan secara intravena selama persalinan elektifseksio sesaria dengan dosis $\mathrm{mg} / \mathrm{kg}$ selama 1 jam, diikuti dengan $1 \mathrm{mg} / \mathrm{kg}$ sepanjang proses kelahiran. Pada persalinan ini, infus ZDV dimulai 4 jam sebelumnya dan dilanjutkansampai tali pusar sudah terjepit. National Guidelines menyarankan pemberian antibiotik peripartum pada saat persalinan untuk mencegah terjadinya infeksi.

Ruangan operasi juga harus dibuat senyaman mungkin untuk mencegah PROM sampai kepala dilahirkan melalui operasi insisi. Kelompok meta - analisis Internasional perinatal HIV, menemukan bahwa resiko transmisi vertikal meningkat $2 \%$ setiap penambahan 1 jam durasi PROM. Jika persalinan sesaria dilakukan setelah terjadi PROM, keuntungan operasi jelas tidak ada. Pada kasus ini, pemilihan jalan lahir harus disesuaikan secara individu. Oleh karena itu usahakan membran tetap intak selama mungkin (Megadhana W,2015).

Infeksi maternal HIV memiliki keterkaitan dengan kelahiran bayi dalam kondisi buruk yaitu kelahiran premature, berat badan lahir rendah, dan retardasi pertumbuhan intrauterin (Brocklehurst \& French, 2005). Ibu hamil positif HIV berpotensi melahirkan bayi dengan APGAR rendah karena asfiksia akibat infeksi maternal yang menyebabkan sintesis dan sekresi surfaktan paru - paru fetus berkurang (Mensah, 2015). Interval untuk mencegah transmisi perinatal (PMTCT), selain terapi ARV dan profilaksis, pemilihan susu formula dibandingkan ASI terbukti dapat menurunkan transmisi HIV dari ibu ke anak dari $15-25 \%$ sampai kurang dari $2 \%$. Persalinan dengan elektif seksio sesaria ternyata juga dapat menurunkan transmisi perinatal. Persalinan ini dinilai dapat meminimalkan terpaparnya janin terhadap darah maternal akibat pecahnya selaput plasenta dan sekresi maternal saat janin melewati jalan lahir. Indikasi persalinan dengan elektif seksio sesaria adalah wanita tanpa pengobatan antivirus, wanita yang mengkonsumsi HAART dengan viral load >50kopi / mL. (Megadhana W,2015).

Setelah melahirkan, ibu sebaiknya menghindari kontak langsung dengan bayi. Secara teori, ASI dapat membawa HIV dan dapat meningkatkan transmisi perinatal. Oleh karena itu, WHO tidak merekomendasikan pemberian ASI pada ibu dengan HIV positif, meskipun mereka mendapatkan terapi ARV. Saran suportif mengenai susu formula pada bayi sangat diperlukan untuk mencegah gizi buruk pada bayi. Semua bayi harus diterapi dengan ARV < 4 jam setelah lahir. Kebanyakan bayi diberikan monoterapi ZDV 2x sehari selama 4 minggu.

Jika ibu resisten terhadap ZDV, obat alternatif bisa diberikan pada kasus bayi lahir dari ibu HIV positif tanpa indikasi terapi ARV. Tetapi untuk bayi berisiko tinggi 
terinfeksi HIV, seperti anak lahir dari ibu yang tidak diobati atau ibu dengan plasma viremia >50kopi/mL HAART tetap menjadi pilihan utama (Megadhana W,2015). Pentingnya pemilihan jenis persalinan yang tepat guna memutus rantai penularan virus HIV/AIDS dari ibu kepada bayi yang dilahirkan menarik peneliti untuk mengetahui efektivitas persalinan elektif pada ibu hamil dengan HIV/AIDS berdasarkan penelitian terdahulu dan teori ilmiah.

\section{Metode}

Desain penelitian ini menggunakan pendekatan study kepustakaan (Library Research) dengan cara mengumpulkan informasi dan data WHO, Kementrian Kesehatan Republik Indonesia, tentang angka kejadian ibu hamil dengan HIV/AIDS, 6 jurnal ilmiah tentang berupa tata laksana maupun faktor risiko yang berhubungan dengan kejadian HIV/AIDS.

\section{Hasil dan Pembahasan}

Berdasarkan hasil review jurnal ilmiah dan teori tentang HIV/AIDS pada ibu hamil dan anjuran persalinan menurut The Society of Obstetricians and Gynaecologists of Canada (SOGC) dan American College of Obstetricians and Gynecologists (ACOG) diketahui:

\section{Penularan HIV/AIDS dalam Kehamilan}

HIV adalah jenis virus RNA rantai tunggal dari keluarga lentivirus memiliki 2 tipe yaitu HIV tipe 1 dan tipe 2 dimana HIV tipe1 lebih kuat, mematikan dan mudah bertransmisi daripada HIV tipe2. HIV masuk ke dalam makrofag dan sel T CD4+ melalui glikoprotein pada permukaan sel menuju reseptor pada sel target (Zorilla, CD, 2009).

Menurut Nursalam, 2009 penularan selama proses persalinan terjadi melalui transfusi fetomaternal atau kontak antara kulit atau membran mukosa bayi dengan darah atau sekresi maternal saat melahirkan. Semakin lama proses persalinan, semakin besar risiko terjadinya penularan. Oleh karena itu, lama persalinan bisa dipersingkat dengan operasi seksio sesaria.

Teori ini sesuai dengan hasil penelitian James DK, Steer PJ, Weiner CP, Gonik B. Human Immunodeficiency Virus. Dalam: High Risk Pregnancy: Management Options. Edisi ke-1. London: W. B. Saunders Company Ltd, 1994 dalam penelitian Ratna Dewi, 2017 dengan judul Peranan Laboratorium Dalam Prevention of Mother to Child Transmission (PMTCT) HIV menyatakan bahwa hampir 90\% kasus infeksi HIV pada anak disebabkan oleh transmisi perinatal akibat penyebaran hematogen.

Beberapa penelitian melaporkan tingginya kasus terjadi akibat terpaparnya intrapartum terhadap darah maternal seperti pada kasus episiotomi, laserasi vagina atau persalinan dengan forsep, sekresi genital yang terinfeksi dan ASI. Frekuensi rata-rata transmisi vertikal dari ibu ke anak dengan infeksi HIV mencapai 25-30\%. Faktor lain yang meningkatkan resiko transmisi ini, antara lain jenis HIV tipe 1, riwayat anak sebelumnya dengan infeksi HIV, ibu dengan AIDS, lahir 
prematur, jumlah CD4 maternal rendah, viral load maternal tinggi, anak pertama lahir kembar, korioamnionitis, persalinan pervaginam dan pasien HIV dengan koinfeksi.

Faktor risiko transmisi /penularan virus HIV juga dilaporkan dalam penelitian oleh Soetrisno, 2017 dengan judul "Faktor risiko yang berhubungan dengan penularan HIV pada ibu yang melahirkan di di delapan rumah sakit milik pemerintah Provinsi Papua Barat yang memiliki program Prevention of Mother to Child Transmission (PMTCT) tahun 2017 dengan metode kohort retrospektif. Melaporkan bahwa prevalensi ibu melahirkan dengan HIV 15.3\% (CI95\%), terbanyak pada usia reproduksi $(85.1 \%)$, sumber penularan utama heteroseksual (100\%). Pendidikan ibu < 9 tahun meningkatkan risiko kejadian HIV pada ibu melahirkan1.4 kali dibandingkan > 9 tahun $(\mathrm{p}=0.01)$. Sosial ekonomi suami yang rendah meningkatkan risiko 5,51 kali dibanding tinggi $(\mathrm{p}=, 0.01)$.

Ibu melahirkan bersuku asli papua mempunyai risiko terkena HIV 3.05 kali dibanding no papua, secara statistik bermakna ( $p<0.01$ ). Domisili ibu melahirkan dikampung meningkat 2.21 kali dibanding kota, secara statistik bermakna $\quad(p<0.01) . \quad$ Kejadian persalinan premature meningkat 1.8 kali pada HIV positif dibanding HIV negatif secara statistik bermakna $(p<0.01)$. Kejadian bayi berat badan lahir rendah meningkat $1.64 \mathrm{kali}$ pada ibu melahirkan HIV positif dibanding HIV negatif secara statistik bermakna $(\mathrm{p}=0.01)$.
Berbeda dengan hasil penelitian sebelumnya Purnaningtyas, 2011 dengan judul Persalinan Pervaginam dan Menyusui sebagai Faktor Risiko Kejadian HIV pada bayi di klinik VCT RSUP Dr. Kariadi tahun 20022011 terhadap 28 responden yang terdiri dari 16 subyek (ibu hamil dengan HIV) dan 12 non subyek (ibu hamil tanpa HIV) didapatkan hasil menunjukkan bahwa persalinan pervaginam (OR 6,07, 95\% CI 1,11-3,24) merupakan faktor risiko yang berpengaruh terhadap kejadian HIV pada bayi.

Penularan HIV tertinggi umumnya terjadi pada saat persalinan ketika kemungkinan terjadi percampuran darah ibu dan lendir ibu dengan bayi hal ini lebih sering terjadi jika plasenta meradang atau terinfeksi. Kulit dari bayi yang baru lahir masih sangat lemah dan mudah terinfeksi jika kontak dengan HIV. Bayi mungkin juga terinfeksi karena menelan darah ataupun lendir ibu. Semakin lama proses persalinan berlangsung, risiko penularan HIV dari ibu ke bayi juga semakin meningkat karena akan semakin lama terjadinya kontak antara bayi dengan darah dan lendir ibu.

Ketuban pecah lebih dari 4 jam sebelum persalinan akan meningkatkan risiko penularan hingga 2 kali lipat jika dibandingkan jika ketuban pecah kurang dari empat jam sebelum persalinan. Faktor lain yang meningkatkan risiko penularan selama proses persalinan adalah penggunaan vakum atau forseps dan tindakan episiotomy. Hal tersebut semakin mendukung hasil penelitian ini, dimana persalinan pervaginam menjadi 
faktor risiko sebesar 46,4\% (Dewantiningrum J, 2011).

Berdasarkan teori dan hasil penelitian diatas peneliti berpendapat bahwa pola transmisi / penularan HIV dalam persalinan dari ibu ke bayi berawal dari transmisi vertikal selama janin dalam kandungan (masa antenatal) melalui antibodi yang dapat menembus plasenta. Seperti pendapat Manuaba, 2008 yang menyatakan bahwa penularan virus HIV disebabkan oleh antibodi yang terinfeksi virus HIV yang sudah terpapar sejak usia kehamilan 13 minggu yang menembus plasenta dan menginfeksi janin secara vertikal melalui sirkulasi uteroplasenta.

Teori ini sejalan dengan hasil Penelitian Marianto , 2019 dengan Judul “ Infeksi Human Immunodeficiency Virus (HIV) dalam Kehamilan" melaporkan bahwa Infeksi HIV selama masa kehamilan dapat menyebabkan transmisi vertikal dari ibu ke anak baik dalam masa kehamilan ataupun saat proses persalinan. Beberapa strategi telah dikembangkan untuk menurunkan transmisi vertikal berupa edukasi kesehatan reproduksi, pencegahan infeksi dengan penggunaan kondom, skrining HIV universal, tatalaksana menggunakan ARV, PrEP (Pre-Exposure Prophylaxis), dan deteksi dini dan tatalaksana infeksi HIV pada ibu hamil.

Diagnosis infeksi HIV dapat dikonfirmasi melalui kultur virus langsung dari limfosit dan monosit darah tepi. Diagnosis juga dapat ditentukan oleh deteksi antigen virus dengan polymerase chain reaction ( $\mathrm{PCR})$. Terlihat penurunan jumlah
CD4, rasio CD4 dan CD8 terbalik dan level serum imunoglobulin meningkat pada HIV positif. Enzyme-linked immunosorbent assay merupakan tes skrining HIV yang paling sering digunakan unruk mengidentifikasi antibodi spesifik virus, baik HIV tipe 1 maupun HIV tipe 2.

Tes ini harus dikonfirmasi dengan Western blot assay atau immunoflourescent antibody assay (IFA), untuk mendeteksi antigen spesifik virus yaitu p24, gp120/160 dan gp41. American Congress of Obstetrics and Gynecology (ACOG) merekomendasikan wanita berumur 19-64 tahun untuk melakukan skrining HIV secara rutin, khususnya wanita yang beresiko tinggi diluar umur tersebut. Pada kunjungan prenatal pertama, ibu hamil harus melakukan skrining untuk infeksi HIV. Apabila ibu menolak untuk melakukan tes, hal tersebut harus dicantumkan ke dalam rekam medisnya dan skrining bisa dilakukan lagi sebelum umur kehamilan 28 minggu. Apabila hasil tes negatif tetapi dokter memutuskan bahwa ibu adalah resiko tinggi terinfeksi HIV, tes bisa diulang kembali pada trimester ketiga (Ratna Dewi, 2017).

Selama masa persalinan virus HIV dapat menginfeksi bayi melalui sekret ibu yang mengandung virus baik dari darah yang berasal dari tindakan episiotomi, luka jalan lahir (ruptur perinemum), cairan ketuban yang pecah sebelum persalinan dimulai (4 jam sebelum persalinan), tindakan pertolongan persalinan tindakan seperti vacum atau forcep. Untuk mengurangi risiko transmisi vertikal tersebut, maka pemerintah menggiatkan 
program Prevention of Mother to Child Transmission (PMTCT) melalui deteksi dini wanita dengan HIV. Sehingga bila wanita tersebut hamil, maka dapat disiapkan semaksimal mungkin untuk mencegah terjadinya transmisi HIV dari ibu ke bayi melalui pemberian obat antiretroviral pada ibu dan pemilihan jenis persalinan sesuai viral load. Melalui deteksi dini, penanganan yang tepat, dan pemantauan yang berkesinambungan diharapkan dapat mengurangi risiko penularan HIV dan meningkatkan kualitas hidup Orang dengan HIV/AIDS (ODHA).

Penatalaksanaan persalinan SC elektif pada ibu bersalin dengan HIV / AIDS

Operasi caesar elektif adalah operasi yang dilakukan satu hingga dua minggu sebelum tanggal kelahiran bayi (Natalova $\mathrm{T}$, 2019). SC elektif adalah suatu tindakan bedah yang dilakukan terjadwal dengan persiapan, dan dilakukan pada pasien dengan kondisi baik, bukan gawat darurat (Sutarno I, 2017). Menurut penelitian yang dilakukan oleh Yudin H, 2012 The Society of Obstetricians and Gynaecologists of Canada (SOGC) dan American College of Obstetricians and Gynecologists (ACOG) merekomendasikan bahwa operasi caesar elektif (operasi caesar sebelum persalinan atau pecah ketuban (ROM) dilakukan untuk pengiriman ketika viral load terdeteksi atau lebih dari 1000 ekslemplar/mL karena terdapat 12 kali lipat peningkatan risiko MTCT. Hal ini didasarkan pada beberapa penelitian yang menunjukkan bahwa kombinasi Zidovudine intrapartum
(ZDV) dan operasi caesar elektif menurun secara signifikan transmisi vertikal dibandingkan dengan mode pengiriman lainnya.

Cara persalinan harus ditentukan sebelum umur kehamilan 38 minggu untuk meminimalkan terjadinya komplikasi persalinan. Sampel plasma viral load dan jumlah CD4 harus diambil pada saat persalinan. Pasien dengan Highly active antiretroviral therapy (HAART) harus mendapatkan obatnya sebelum persalinan. Semua ibu hamil dengan HIV positif disarankan untuk melakukan persalinan dengan seksio sesaria. Infus ZDV diberikan secara intravena selama persalinan elektif seksio sesaria dengan dosis $\mathrm{mg} / \mathrm{kg}$ selama 1 jam, diikuti dengan $1 \mathrm{mg} / \mathrm{kg}$ sepanjang proses kelahiran. Pada persalinan ini, infus ZDV dimulai 4 jam sebelumnya dan dilanjutkan sampai tali pusar sudah terjepit (Megadhana W, 2015).

Tindakan SC elektif dilakukan apabila tidak memungkinkan dilakukan persalinan pervaginal disebabkan adanya resiko terhadap ibu atau janin (Saifudin, 2002). Serta adanya indikasi fetal dan maternal (Alomedika,2017). Teori ini sesuai dengan hasil penelitian yang dilakukan oleh Purnaningtyas (2011) bahwa ibu hamil dengan HIV bersalin secara pervaginam meningkatkan risiko penularan terhadap kejadian HIV pada bayi. Ibu rumah tangga penderita HIV / AIDS dalam upaya pencegahan dan penularan terhadap keturunannya melakukan proteksi diri dengan melahirkan secara seksio sesaria (Lina, 2012). 
Hal ini ditegaskan oleh penelitian Gondo (2011) bahwa persalinan dengan seksio sesaria berencana sebelum saat persalinan tiba merupakan pilihan pada ODHA.

National Guidelines menyarankan pemberian antibiotik peripartum pada saat persalinan untuk mencegah terjadinya infeksi.

Ruangan operasi juga harus dibuat senyaman mungkin untuk mencegah PROM sampai kepala dilahirkan melalui operasi insisi. Kelompok meta - analisis Internasional perinatal HIV, menemukan bahwa resiko transmisi vertikal meningkat $2 \%$ setiap penambahan 1 jam durasi PROM. Jika persalinan sesaria dilakukan setelah terjadi PROM, keuntungan operasi jelas tidak ada. Pada kasus ini, pemilihan jalan lahir harus disesuaikan secara individu. Oleh karena itu usahakan membran tetap intak selama mungkin. Berdasarkan penelitian yang dilakukan oleh ACOG pada tahun 2000, pasien HAART dengan viral load >1000 kopi/mL, harus konseling berkenaan dengan keuntungan yang didapat dari persalinan elektif seksio sesaria dalam menurunkan resiko transmisi vertikal pada perinatal.

Berdasarkan teori dan hasil penelitian diatas maka peneliti berpendapat bahwa SC Elektif merupakan operasi / bedah yang dilakukan secara terjadwal atau terencana sebelum adanya tanda proses persalinan berlangsung, dan hanya dilakukan pada pasien dalam kondisi baik bukan gawat darurat, serta dilakukan pada pasien yang memiliki kontraindikasi persalinan secara pervaginam dan memiliki indikasi fetal serta maternal.
Teori ini sejalan dengan hasil penelitian yang dilakukan oleh Widianto, 2014 menyatakan bahwa persalinan sesaria yang dilakukan berdasarkan indikasi bayi, indikasi ibu dan adanya penyakit penyerta. Berdasarkan indikasi bayi diketahui lebih dari separuh $(52,3 \%)$ persalinan secara elektif dilakukan karena letak sungsang atau malposisi. Berdasarkan indikasi ibu diketahui sebanyak $(15,6 \%)$ persalinan secara elektif karena kondisi panggul ibu yang sempit dan disertai penyakit penyerta seperti hipertensi.

Berbagai studi merekomendasikan metode persalinan Caesar secara elektif (operasi terjadwal) diketahui dapat menurunkan resiko terjadinya MTCT hingga $80 \%$. Meta analisis ini mendapatkan bayi yang dilahirkan secara operasi Caesar terjadwal mengalami infeksi HIV lebih rendah dibandingkan dengan bayi yang dilahirkan secara per vaginam $(1,7 \%$ vs $10,6 \%)$.

Bayi yang dilahirkan secara operasi caesar memiliki risiko 0,43 kali lipat mengalami infeksi HIV dibandingkan dengan bayi yang lahir secara per vaginam. Pada meta analisis ini dapat disimpulkan bahwa operasi caesar terjadwal dapat bersifat protektif terhadap penularan infeksi HIV ke bayi apabila ibu tidak menjalani pengobatan antiretroviral dengan rutin (dr.Gisheila Ruth Anggitha, 2017). Teori ini sesuai dengan meta - analisis pada 15 buah penelitian yang melibatkan 7.800 pasangan ibu anak membuktikan bahwa bayi yang dilahirkan secara seksio sesaria yang dilakukan sebelum ketuban pecah mempunyai kejadian transmisi 
vertikal jauh lebih rendah bila dibandingan dengan kelahiran per vaginam (Suradi R, 2002).

\section{Penatalaksanaan Pada Bayi Baru Lahir Dari Ibu Dengan HIV / AIDS.}

Infeksi pada bayi atau anak oleh virus HIV (Human Immunodeficiency Virus) umumnya terjadi secara vertikal (dari ibu yang mengandungnya) maupun secara horizontal melalui transfusi produk darah atau penularan lain yang jarang. Di seluruh dunia, penyebab kematian karena HIV / AIDS sebesar 7,7\% dari seluruh penyebab kematian. AIDS ditemukan pada 19\% kematian bayi dan kenaikan sebesar $36 \%$ kematian balita diseluruh dunia.

Di indonesia, sejak dimunculkan ke publik tahun 1996 dimulai dengan 1 anak, hingga kini sudah tercatat $>100$ anak yang terpapar HIV baik terinfeksi maupun tidak. Secara sporadis sudah dilaporkan munculnya kasus anak yang terinfeksi HIV diberbagai tempat di Indonesia (Williams \& Wilkins, 2003).

Infeksi maternal HIV memiliki keterkaitan dengan kelahiran bayi dalam kondisi buruk, yaitu kelahiran prematur, berat badan lahir rendah, dan reterdasi pertumbuhan intrauterin. (Brocklehurst \& French,2005). Ibu hamil positif HIV berpotensi melahirkan bayi dengan APGAR rendah karena asfiksia akibat infeksi maternal yang menyebabkan sintesis dan sekresi surfaktan paru - paru fetus berkurang (Mensah, 2015).

Hasil penelitian dengan judul "Tatalaksana Bayi dari Ibu Pengidap
HIV/AIDS tahun 2003 menyatakan bahwa pemberian satu kali Nevirapine pada saat persalinan kepada ibu dan kemudian dilanjutkan dengan pemberian satu kali pada bayi pada usia 48-72 jam setelah lahir dapat menurunkan transmisi vertical sebanyak 50\% bila dibandingkan dengan pemberian zidovudine oral waktu intrapartum dan pada bayi selama satu minggu. Kombinasi dua obat antiretroviral atau lebih ternyata sangat mengurangi transmisi vertikal apalagi bila dikombinasi dengan persalinan melalui seksio sesaria serta tidak memberikan ASI (Suradi, 2003).

Secara teori, ASI dapat membawa HIV dan dapat meningkatkan transmisi perinatal. Oleh karena itu, WHO tidak merekomendasikan pemberian ASI pada ibu dengan HIV positif, meskipun mereka mendapatkan terapi ARV. Saran suportif mengenai susu formula pada bayi sangat diperlukan untuk mencegah gizi buruk pada bayi. Menurut penelitian yang dilakukan di Eropa, semua wanita dengan HIV positif direkomendasikan untuk mengkonsumsi kabergolin $1 \mathrm{mg}$ oral dalam 24 jam setelah melahirkan, untuk menekan laktasi (Megadhana W,2015).

Air susu ibu mengandung partikel nustrisi dan vitamin, sel - sel utuh, bakteri komensal, antibodi, komplemen, komponen kimiawi yang berperan dalam komunikasi antar sel, dan kuman penyakit dalam bentuk bakteri atau virus. Sel yang berada dalam ASI memiliki konsentrasi $10.000-1.000 .000$ sel/mL, yang meliputi sel epitel aluran ASI 
makrofag dan limposit. Makrofag adalah sel dalam tubuh manusia yang berperan dalam memakan sel lain yang tidak berfungsi, kuman dan segala sesuatu yang diaggap akan membahayakan tubuh manusia. Sedangkan sel limfosit adalah salah satu jenis sel leukosit yang berperan sebagai konduktor respon imun tubuh terhadap benda asing atau dianggap asing (IDAI, 2015).

Berdasarkan teori serta hasil penelitian diatas, peneliti menyimpulkan bahwa penatalaksanaan pada bayi baru lahir dari ibu dengan HIV / AIDS dapat dilakukan pemberian satu kali Nevirapine pada saat persalinan kepada ibu dan kemudian dilanjutkan dengan pemberian satu kali pada bayi pada usia 48-72 jam setelah lahir, serta disarankan agar tidak memberikan ASI kepada bayi nya agar terhindar dari transmisi vertikal melalui ASI dan pemberian susu formula sangat disarankan agar menghindari bayi dari gizi buruk. Jadi untuk penatalaksanaan yang dapat dilakukan pada bayi baru lahir dari ibu dengan HIV adalah dengan pemberian obat terapi serta tidak memberikan ASI kepada bayi.

\section{Kesimpulan}

Penularan HIV / AIDS dapat terjadi pada masa kehamilan karena penurunan sel $\mathrm{T}$ yang meningkatkan risiko terpapar virus dan Selama persalinan bayi juga dapat tertular darah atau cairan vagina melalui paparan virus yang tertelan pada jalan meningkatkan risiko transmisi dua kali lipat. SC Elektif merupakan metode persalinan yang dianjurkan untuk ibu hamil positif HIV karena dapat menurunkan risiko MTCT dengan viral load > 1000 ekslemplar / Ml.

\section{Daftar Pustaka}

Afriyanti D, 2012. Faktor - faktor yang berhubungan dengan perilaku bidan dalam pencegahan risiko penularan HIV / AIDS pada pertolongan persalinan normal, diakses 15 juli 2020, 12.45 WIB

Brocklehurst \& French, 2005. Hubungan Ibu hamil positif HIV / AIDS dengan APGAR score Bayi di RS dr.Soebandi

Kemenkes RI, 2019. Kasus Baru Penderita HIV di Indonesia Dan Sebarannya di Seluruh Pulau Kalimantan Tahun 2016 $-2018$

Manuaba, 2008. Kehamilan dan Gangguan dalam Kehamilan. Jakarta: Trans Medika

Mengadhana W, 2015. Tatalaksana Infeksi HIV dalam Kehamilan, https://www.google.co.id.diakses: 20 Mei 2020, 17.50 WIB

Marks, 2012. Pengetahuan ibu HIV mempengaruhi perilaku pencegahan penularan HIV / AIDS dari ibu ke bayi. https://www.google.co.id/searchsclint= psy-auklmu=serpmku8Noklnoj=pdf, diakses : 20 agustus 2020, 17.50 WIB

Mansjoer, 2000. Konsep Sectio Caesaria, https://www.google.co.id/searchsclint= psy-abq=serp-sc.pdfNSCRnoj=pdf, diakses : 22 juli 2020, 17.50 WIB

Mensah, 2015. Hubungan Ibu hamil positif HIV / AIDS dengan APGAR score Bayi di RS dr.Soebandi, https://www.google.co.id/searchsclint= psy-abq=serpNSCRnoj=pdf, diakses: 20 Mei 2020, 17.50 WIB

Natalova T, 2019. Indikasi Sectio Caesaria, https://www.google.co.id/searchsclint= psy-abq=serpNSCRnoj=pdf, diakses : 
25 Mei 2020, 17.50 WIB

Nursalam, 2009. Proses Penularan HIV / AIDS selama persalinan, https://www.google.co.id/searchsclint= psy-abq=serpNSCRnoj=pdf, diakses : 11 Agustus 2020, 00.50 WIB

Purnaningtyas, 2011. Persalinan Pervaginam dan Menyusui sebagai Faktor Risiko Kejadian HIV pada Bayi di Klinik VCT RSUP Dr.Kariadi, https://www.google.co.id/searchsclint= psy-abq=serpNSCRnoj=pdf, diakses : 12 Mei 2020, 13.50 WIB

Rohan H, 2016. Kesehatan Reproduksi. Malang: Citra Intrans Selaras

Suradi, 2003. Tata Laksana Bayi baru Ibu pengidap HIV / AIDS, https://www.google.co.id. diakses: 05 Agustus 2020, 17.50 WIB

Suherlim, 2015. Karakteristik Penderita HIV pada Ibu Hamil di Klinik Prevention Mother Of Child Transmission (PMTCT) Poli Kebidanan RSUP sanglah Denpasar, Diakses : 6 Juli 2020, 09.00 WIB

Subrayogo, 2001. Teknik Analisis Data, Diakses: 9 Agustus 2020

Permenkes RI No 52 tahun 2017, Eliminasi Penularan Virus HIV,Sfilis, dan Hepatitis B, diakses : 10 april 2020, 08.30 WIB 